\title{
CHARACTERISITC STUDY OF NANOSILICA IN DURABILITY ON VARYING WATER-CEMENT RATIO
}

\author{
Ranjith Kumar L \\ Research Scholar, Department of Civil Engineering, \\ Sathyabama Institute of Science and Technology, Chennai, Tamilnadu, India. \\ Dr. Mageswari. M \\ Professor, Department of Civil Engineering, \\ Panimalar Engineering College, Chennai, Tamilnadu, India.
}

\begin{abstract}
The purpose of this work is to describe the effect of durability aspect of Nano silica when added to concrete. The use of Nanosilica in concrete is to reduce the cement content in concrete mix since the design consumes almost the total cement production in the world. Nanotechnology is one of the most active research areas which has wide applications in almost all the fields. Researchers are focusing to improve the durability and sustainability of concrete by incorporating Nanosilica. This paper summarizes the effect of Nanosilica addition on compressive strength, chloride penetration test, electrical resistivity and carbonation resistance test in varying water-cement ratio of $0.65,0.55$ and 0.5 and $N S$ in $0 \%, 0.5 \%, 1 \%$ and $1.5 \%$ by weight.
\end{abstract}

The effect of certain NS dosage on compressive strength and durability properties for high strength concrete mix was different than low strength mixes.

Keywords: Nanosilica, durability, water-cement ratio, strength

Cite this Article: Ranjith Kumar L and Dr. Mageswari M, Characterisitc Study of Nanosilica in Durability on Varying Water-Cement Ratio. International Journal of Advanced Research in Engineering and Technology, 10(4), 2019, pp. 86-93.

http://iaeme.com/Home/issue/IJARET?Volume=10\&Issue $=4$

\section{INTRODUCTION}

Nanotechnology is one of the most active research areas which have wide applications in almost all the fields. As concrete is most usable material in construction industry it's been required to improve its quality. Improving concrete properties by addition of Nano particles have shown significant improvement than conventional concrete. It improves the material bulk properties. Nano is used to obtain thinner final products and faster setting time. It is cost 
effectiveness and it has lowered levels of environmental contamination. A concrete made with Portland cement particles that are less than $500 \mathrm{~nm}$ as a cementing agent is called Nano concrete. Currently cement particle sizes range from a few Nano-meters to a maximum of about 100 micro meters.

The production method of Nano silica is based on a gel process at room temperature. In this process the materials $\mathrm{Na}_{2} \mathrm{SiO}_{4}$ are added to a solvent and the $\mathrm{pH}$ of the solution is changed, reaching the precipitation of silica gel. The produced gel is aged and filtered. Nano materials are defined as a set of substances where at least one dimension is less than approximately 100 nanometres. Some of main Nano materials used in concrete are Carbon Nanotubes, Nanosilica and Polycarboxylates. Properties of Nanosilica includes high compressive strengths, high workability with reduced water-cement ratio, use of super plasticizing additives is unnecessary, fill up all the micro pores and micro spaces and cement saving is up to $35-45 \%$.

\section{PROPERTIES OF NANOSILICA}

Table 1 Properties of Nanosilca

\begin{tabular}{|c|c|}
\hline Physical Properties & Chemical Properties \\
\hline Colour - White & $\mathrm{pH}-4.12$ \\
\hline $\mathrm{SG}-1.12$ & $\mathrm{SiO}_{2}-99.1 \%$ \\
\hline Particle size $-17 \mathrm{~nm}(\mathrm{TEM})$ & $\mathrm{Carbon}-6 \%$ \\
\hline Solid Content $-39 \%$ & $\mathrm{Chloride}-6 \%$ \\
\hline Tamped density $-44 \mathrm{~g} / \mathrm{L}$ & $\mathrm{Al}_{2} \mathrm{O}_{3}-0.5 \%$ \\
\hline Loss on dry at $10 \mathrm{~S}^{\circ} \mathrm{C}-0.47$ & $\mathrm{TiO}_{2}-0.4 \%$ \\
\hline Loss on ignition at $1000^{\circ} \mathrm{C}-0.66$ & $\mathrm{Fe}_{2} \mathrm{O}_{3}-0.1 \%$ \\
\hline Specific surface area $-202 \mathrm{~m}^{2} / \mathrm{g}$ & \\
\hline
\end{tabular}

\section{MATERIAL TESTING RESULTS}

Table 2 Material Testing Results

\begin{tabular}{|c|c|}
\hline Properties & Result \\
\hline Specific Gravity of Fine Aggregate & 2.66 \\
\hline Fineness modulus of fine aggregate & $4.14 \%$ \\
\hline Specific Gravity of Coarse Aggregate & 2.68 \\
\hline Fineness modulus of Coarse aggregate & $7.13 \%$ \\
\hline Consistency & Time for remolding is $15 \mathrm{Sec}-$ Concrete is very stiff \\
\hline Flow Value & $6 \%$ \\
\hline
\end{tabular}

\section{SLUMP VALUES}

Table 3 Slump Test Results

\begin{tabular}{|c|c|c|c|c|c|c|c|c|}
\hline \multirow{2}{*}{$\mathbf{W} / \mathbf{C}$} & \multirow{2}{*}{ NS (\%) } & \multirow{2}{*}{ Cement } & \multirow{2}{*}{ NS } & \multicolumn{3}{|c|}{ Composition $\mathrm{kg} / \mathrm{m}^{3}$} & \multirow{2}{*}{ SP } & \multirow{2}{*}{$\begin{array}{c}\text { Slump } \\
(\mathrm{mm})\end{array}$} \\
\hline & & & & Water & FA & $\mathrm{CA}$ & & \\
\hline \multirow{4}{*}{0.65} & 0 & 308 & - & \multirow{4}{*}{200} & \multirow{4}{*}{924} & \multirow{4}{*}{924} & 1.5 & 175 \\
\hline & 0.5 & 306.5 & 1.5 & & & & 1.5 & 120 \\
\hline & 1 & 304.9 & 3.1 & & & & 1.5 & 75 \\
\hline & 1.5 & 303.4 & 4.6 & & & & 1.5 & 30 \\
\hline
\end{tabular}




\begin{tabular}{|c|c|c|c|c|c|c|c|c|}
\hline \multirow{2}{*}{$\mathbf{W} / \mathbf{C}$} & \multirow{2}{*}{ NS (\%) } & \multirow{2}{*}{ Cement } & \multirow{2}{*}{ NS } & \multicolumn{3}{|c|}{ Composition $\mathrm{kg} / \mathrm{m}^{3}$} & \multirow{2}{*}{ SP } & \multirow{2}{*}{$\begin{array}{c}\text { Slump } \\
\text { (mm) }\end{array}$} \\
\hline & & & & Water & FA & $\mathrm{CA}$ & & \\
\hline \multirow{4}{*}{0.55} & 0 & 344 & - & \multirow{4}{*}{189} & \multirow{4}{*}{924} & \multirow{4}{*}{924} & 2.4 & 240 \\
\hline & 0.5 & 342.3 & 1.7 & & & & 2.4 & 105 \\
\hline & 1 & 340.6 & 3.4 & & & & 2.4 & 40 \\
\hline & 1.5 & 338.8 & 5.2 & & & & 2.4 & 40 \\
\hline \multirow{4}{*}{0.5} & 0 & 366 & - & \multirow{4}{*}{183} & \multirow{4}{*}{922} & \multirow{4}{*}{922} & 1.8 & 50 \\
\hline & 0.5 & 364.2 & 1.8 & & & & 2.6 & 80 \\
\hline & 1 & 362.3 & 3.7 & & & & 3.1 & 150 \\
\hline & 1.5 & 360.5 & 5.5 & & & & 5.5 & 60 \\
\hline
\end{tabular}

Addition of $1.5 \%$ NS decrease the slump from 175 to $240 \mathrm{~mm}$ as a reference slump of concrete with $\mathrm{w} / \mathrm{c}=0.65$ and 0.55 to 30 and $40 \mathrm{~mm}$. This could be by the formation of structure that has high water retention after the addition of NS. The amount of lubricating water in the mixture was reduced; thus, viscosity of fresh concrete may increase and slump may decrease. The slump value for $\mathrm{w} / \mathrm{c}=0.5 \mathrm{did}$ not decrease with respect to increasing dosage of NS, since higher amount of SP was used for better workability during casting.

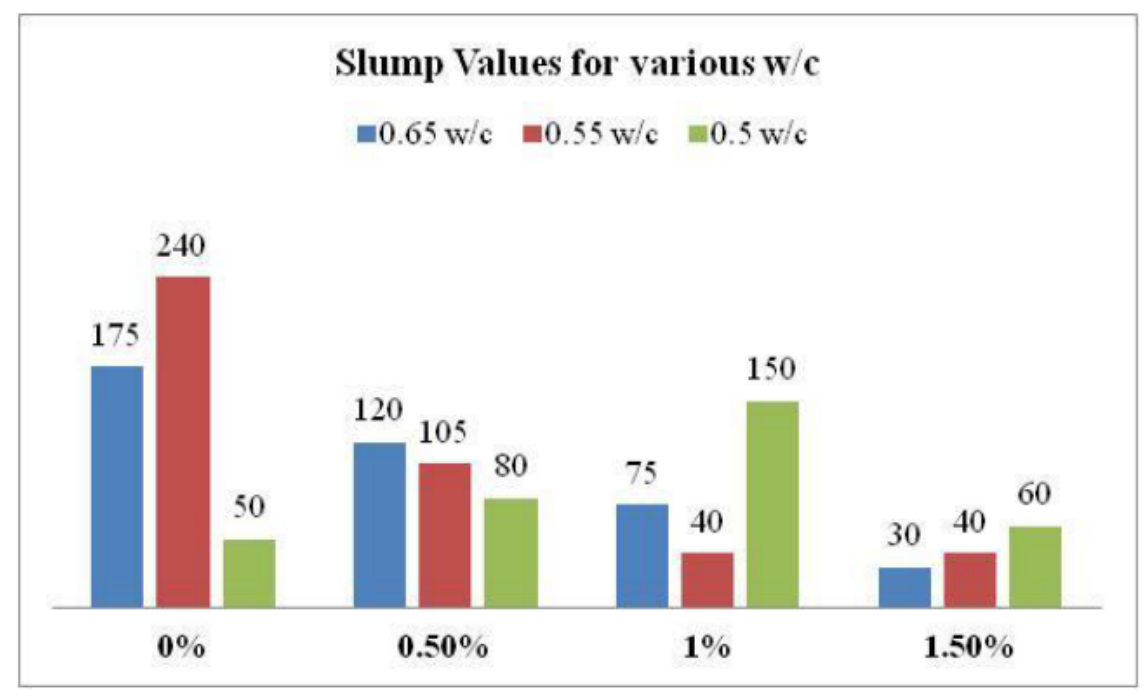

Figure 1 Slump Test Values on Varying w/c and Nano silica percentage

\section{SAMPLE PREPARATION AND METHODS}

Concrete samples with w/c ratios of $0.65,0.55$ and 0.5 were cast. For each w/c ratios three NS contents of $0.5,1$, and $1.5 \%$ with respect to cement mass were considered. For each type of concrete 4 cubes of $150 \times 150 \times 500 \mathrm{~mm}$ were cast for compressive strength. A slab with $500 \times 395 \times 60 \mathrm{~mm}$ dimension was also cast. Cylindrical samples with nominal diameter $100 \mathrm{~mm}$ diameters were cored from the slab at the age of 28 days of curing. The surface in contact with mould was ground, while the casting surface remained unchanged.

\subsection{COMPRESSIVE STRENGTH}

The compressive strength test was performed on cubes moist in curing chamber for 7 and 28 days. 


\subsection{CHLORIDE PENETRATION TEST}

The specimens were placed in vacuum container with absolute pressure for $3 \mathrm{~h}$. The container was filled with demineralized water for $1 \mathrm{~h}$. Soon after, the samples were placed in the lab for 2-4 $\mathrm{h}$ in order for their surface to become dry. All the surfaces but one (mould surface) were covered with epoxy resin and immersed in saturated calcium hydroxide for $18 \mathrm{~h}$ and were finally immersed in sodium chloride solution. Chloride content (\%) of each layer was obtained and apparent chloride diffusion coefficient $D_{\text {app }}$ and surface chloride content $C S$ were obtained through the interpolation.

\subsection{ELECTRICAL RESISTIVITY}

The electrical resistivity test was done by measuring conductance, $G$, across cylindrical specimens. The mould surface of the samples was not ground for this test. The samples were immersed in water and kept at $20-25 \circ \mathrm{C}$ temperature; the conductance was recorded. The conductance was then converted to electrical resistivity, $\rho$, in $\Omega \mathrm{m}$

Electrical resistivity $\rho=\frac{\mathrm{A}}{(1 \times \mathrm{G})}$

Where, $A=$ surface area; $1=$ height of samples

\subsection{CARBONATION RESISTANCE}

Cylindrical specimens were conditioned inside the lab for 14 days with $18-25^{\circ} \mathrm{C}$ temperature and $50-65 \%$ relative humidity and the side surface of the specimens was then covered with epoxy resin. The depth of carbonation was measured (by $0.5 \mathrm{~mm}$ accuracy) after 45 and 135 days by phenolphthalein indicator. The data was interpolated with and carbonation coefficient $K(\mathrm{~mm} / \sqrt{\text { year}})$ was determined:

$$
\mathrm{X}=\mathrm{K} V_{\mathrm{t}}
$$

\section{RESULT AND DISCUSSIONS}

\subsection{COMPRESSIVE STRENGTH RESULTS}

The 28 days compressive strength with $\mathrm{w} / \mathrm{c}=0.65$ improved considerably by NS addition from control value of 34.3 to $43.4 \mathrm{MPa}$ for $1.5 \% \mathrm{NS}$ addition. The 7 days strength increase from 30 to $35.6 \mathrm{MPa}$. For $\mathrm{w} / \mathrm{c}=0.55$, the 28 -day strength was elevated moderately from control mix 47.5 to $56.3 \mathrm{MPa}$ with $1 \% \mathrm{NS}$ addition. The 7 days strength increase from 42.2 to $47.5 \mathrm{MPa}$. No change was observed in the 28-day strength when $\mathrm{w} / \mathrm{c}=0.5$, while 7 days strength raised from 47.5 to $50.6 \mathrm{MPa}$ with $1.5 \mathrm{NS}$

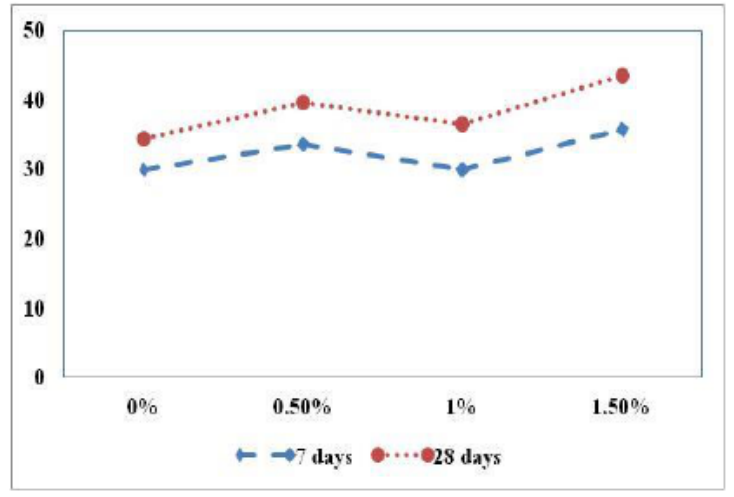

Figure 1 - Compressive Strength for w/c $=0.65$

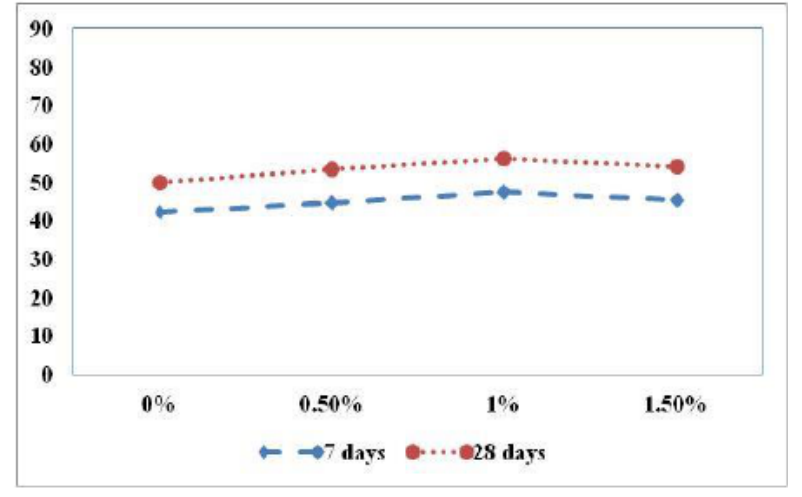

Figure 2 - Compressive Strength for $w / c=0.55$ 


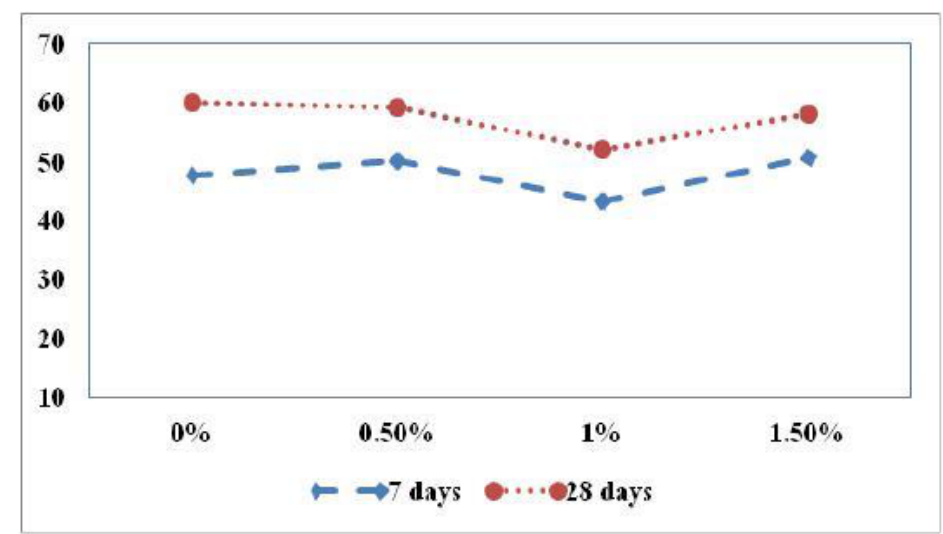

Figure 3 - Compressive Strength for w/c $=0.5$

\subsection{CHLORIDE PENETRATION RESISTANCE}

The apparent chloride diffusion coefficient, $D_{\text {app }}$ and surface chloride content $C_{s}$ of each concrete were calculated and presented in figures. For $\mathrm{w} / \mathrm{c}=0.65$, the $\mathrm{D}_{\text {app }}$ decreased from reference value 19.1 to $16.2 \times 10^{-12} \mathrm{~m}^{2} / \mathrm{s}$ for $0.5 \% \mathrm{NS}$ and increased to $32 \times 10^{-12} \mathrm{~m}^{2} / \mathrm{s}$ for $1 \%$ $\mathrm{NS}$; then it decreased to $20.9 \times 10-12 \mathrm{~m}^{2} / \mathrm{s}$ for $1.5 \% \mathrm{NS}$, close to reference value. For $\mathrm{w} / \mathrm{c}=0.55$, the $D_{\text {app }}$ decreased from reference value 18.2 to $12 \times 10^{-12} \mathrm{~m}^{2} / \mathrm{s}$ for $0.5 \% \mathrm{NS}$ and increased with addition of higher dosage.

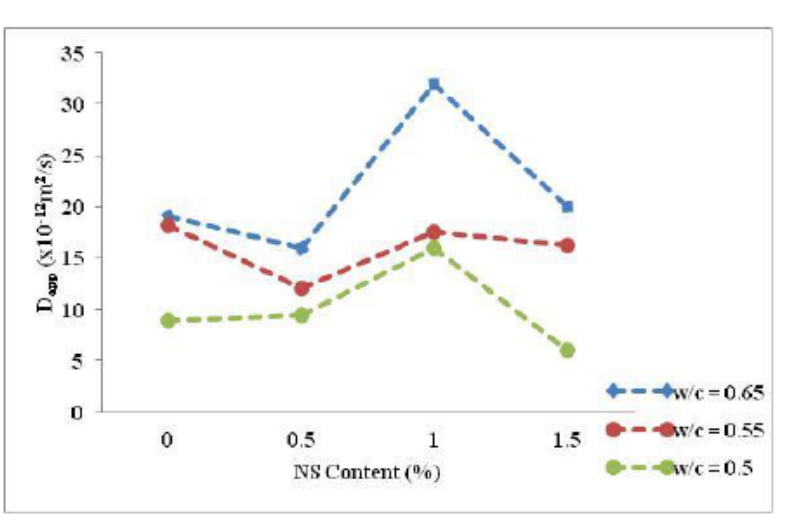

Figure $4-\mathrm{D}_{\text {app }}$ for $\mathrm{w} / \mathrm{c}=0.65$

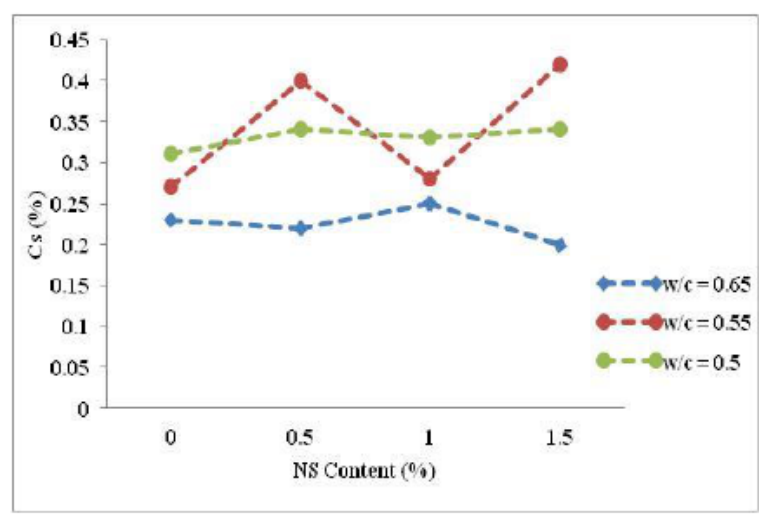

Figure $5-\mathrm{D}_{\text {app }}$ for $\mathrm{w} / \mathrm{c}=0.55$

\subsection{ELECTRICAL RESISITIVITY RESULTS}

The average electrical resistivity after immersion with water and the resistivity after drop is labelled as $\rho$ i then resistivity increased and the average value after 85 days is $\rho 85$. An addition of $0.5 \%$ of NS led $\rho$ i to increase with respect to reference from 52 to 59 ' $\Omega \mathrm{m}, 55$ to $63 \Omega \mathrm{m}$ and 68 to $76 \Omega \mathrm{m}$ for $\mathrm{w} / \mathrm{c}=0.65,0.55$ and 0.5 respectively. The highest reading of $\rho \mathrm{i}$ was $90 \Omega \mathrm{m}$ for $1.5 \% \mathrm{NS}$ with $\mathrm{w} / \mathrm{c}=0.5$. The $\rho 85$ is close to ultimate and showed approximately similar trend with that of $\rho$ i by increasing NS content. 


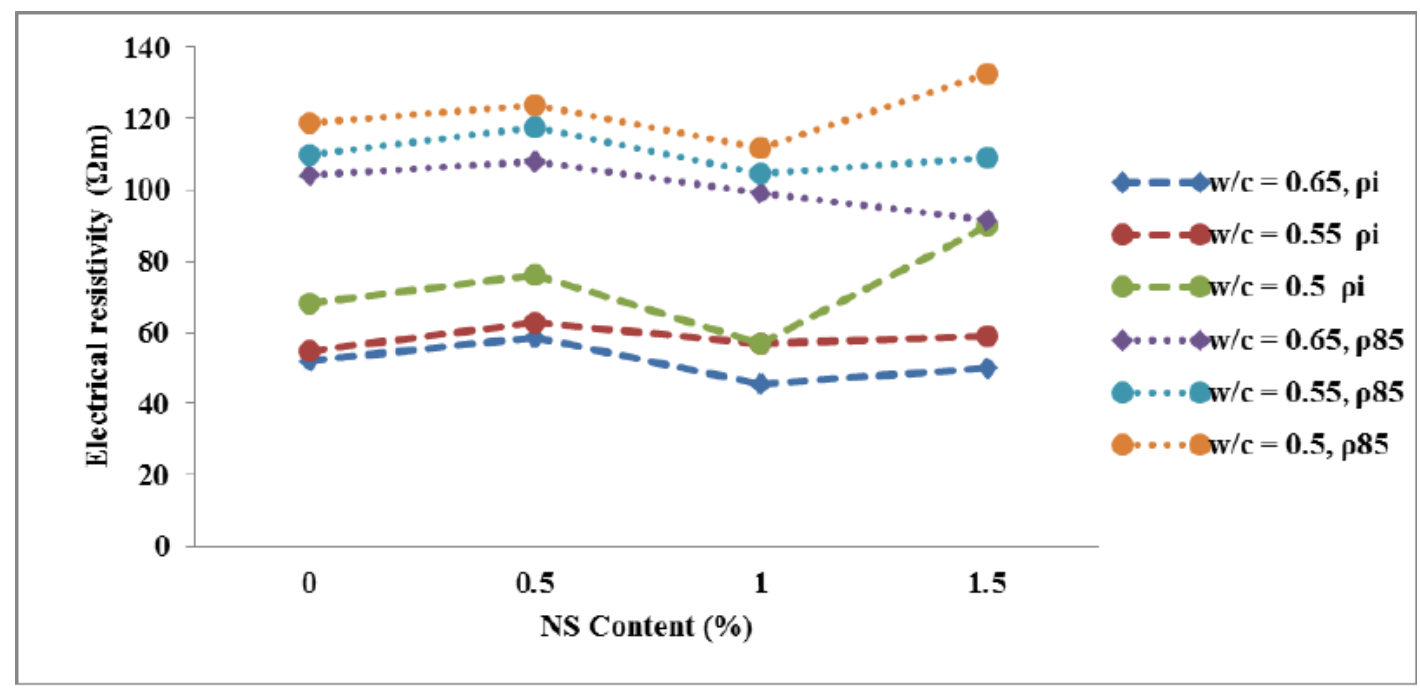

Figure 6 - Electrical Resistivity result for $\mathrm{w} / \mathrm{c}=0.65,0.55$ and 0.5

\subsection{CARBONATION RESISTANCE}

For $\mathrm{w} / \mathrm{c}=0.65, \mathrm{~K}$ increased from control of 16 to a maximum of $24 \mathrm{~mm} / \sqrt{\text { year }}$ for $1 \% \mathrm{NS}$ addition. For $\mathrm{w} / \mathrm{c}=0.55, \mathrm{~K}$ was reduced from 15 to a minimum of $12 \mathrm{~mm} / \sqrt{\text { year }}$ for $1 \% \mathrm{NS}$. For $\mathrm{w} / \mathrm{c}=0.5$, no significant changes for $\mathrm{K}$ values were observed. A typical curve of carbonation depth versus time of exposure is presented.

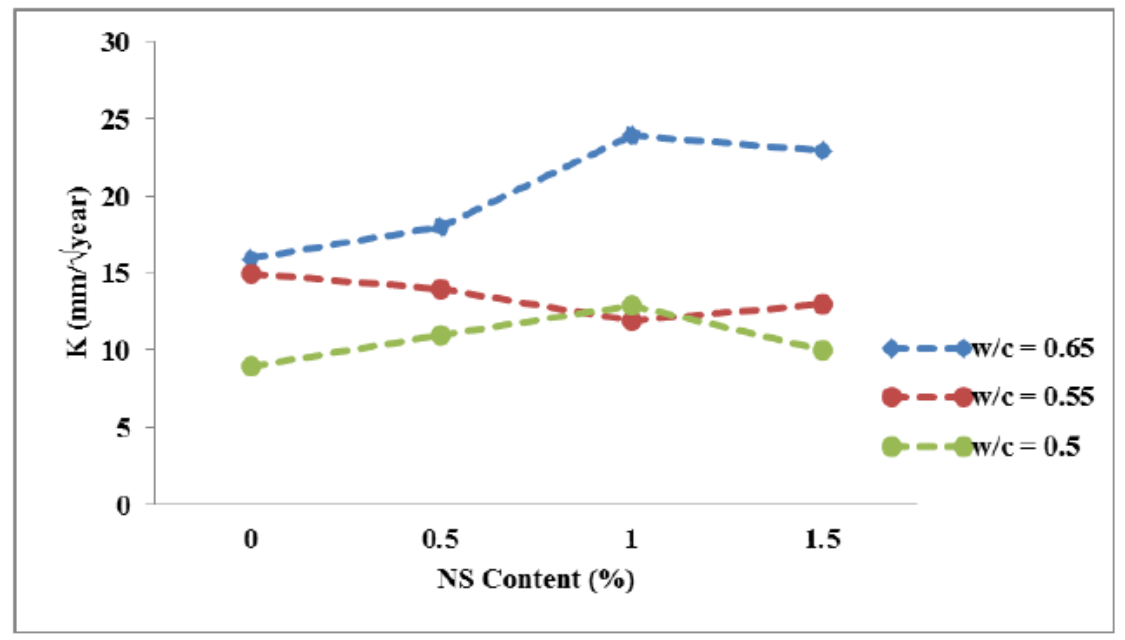

Figure 7 - Carbonation resistance test result for $\mathrm{w} / \mathrm{c}=0.65,0.55$ and 0.5

\subsection{RELATIVE VALUE DETERMINATION}

The Relative value is defined as the ratio between the samples containing NS and that of the corresponding control with similar w/c ratio and curing time, multiplied by 100 . A value above $100 \%$ shows an increase in the property, while below $100 \%$ shows a decrease. 


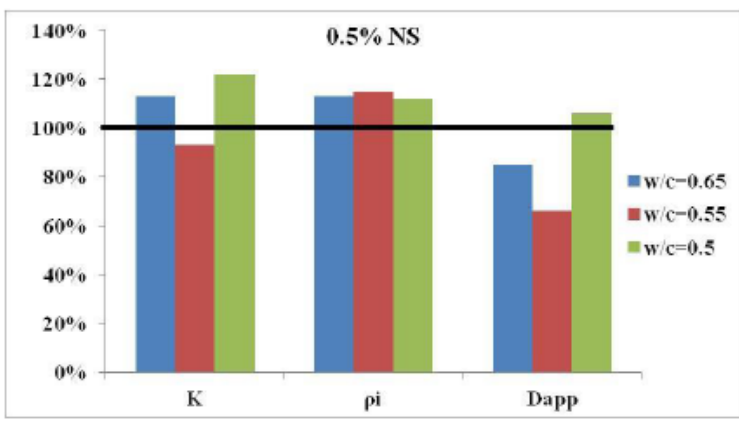

Figure 8 - Relative value for $0.5 \%$ NS

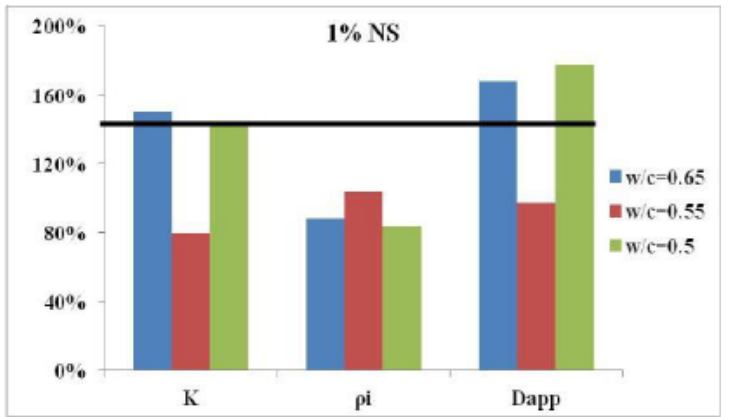

Figure 9 - Relative value for $1 \%$ NS

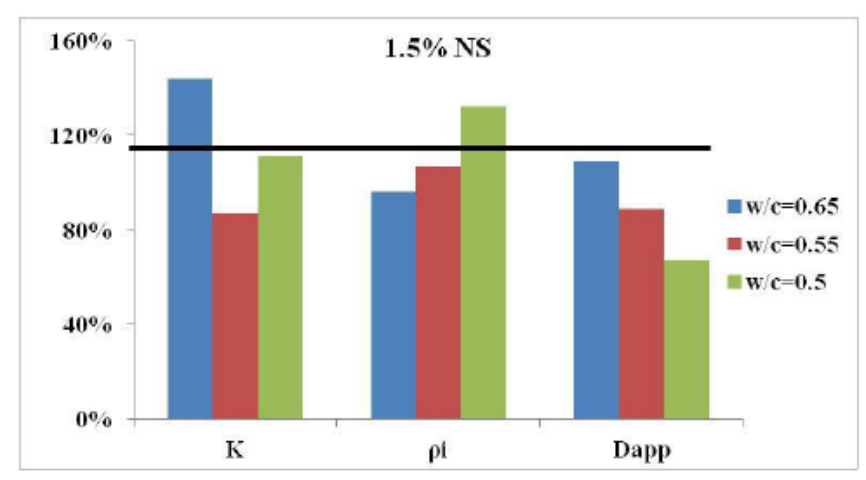

Figure 10 - Relative value for $1.5 \%$ NS

\section{CONCLUSIONS}

- Effect of certain NS dosage on compressive strength and durability properties for high strength concrete mix was different than low strength mixes

- By the incorporation of $1.5 \%$ NS into concrete with $\mathrm{w} / \mathrm{c}=0.65,0.55$ and 0.5 , strength gains $41 \%, 6.5 \%$ and nil respectively

- Durability properties of concrete with different w/c ratios shows highly varying tendency by increasing NS dosage.

- Apparent chloride diffusion coefficient of concrete decreased with $0.5 \%$ NS addition for $\mathrm{w} / \mathrm{c}=0.65$ and 0.55 however it did not decrease with the addition of higher NS as $0.5 \%$

- The electrical resistivity of saturated specimen increased after the addition of $0.5 \%$ NS for all $\mathrm{w} / \mathrm{c}$ ratio. For $\mathrm{w} / \mathrm{c}=0.5$, it also increased for $1.5 \% \mathrm{NS}$ addition

- NS addition for $\mathrm{w} / \mathrm{c}=0.65$ the carbonation coefficient was elevated from the reference of 16 to $23 \mathrm{~mm} / \square$ year by $1 \% \mathrm{NS}$

\section{REFERENCES}

[1] Aswini Devi A.S (2016), "Experimental Investigation of durability characterisitcs of concrete by adding Nano Silica, Glass fibre and partial replacement of cement by Flyash" International Journal of Engineering Research \& Technology (IJERT), Volume 4, Issue 08, pp. 1-4, ISSN - 2278-0181.

[2] Belkowitz, J. and Armentrout, D. L. (2009). The Investigation of Nano Silica in the Cement Hydration Process. ACI Special Publication 267(8): 87-100.

[3] G. Yamini and Dr. S. Siddiraju (2016), An Experimental Research on Strength Propereties of Concrete by The Influence of Flyash and Nanosilica as A Partial Replacement of 
Cement. International Journal of Civil Engineering and Technology, 7(3), 2016, pp.306315.

[4] Surenra P. Shah, et al. (2010). "Controlling Properties of Concrete through Nano Technology" (ACBM Centre, North Western University, USA), Proc. of the International Conference on advances in Concrete, ICI-ACECON 2010, 5-9 Dec., IIT, Madras, India, PP $1-8$.

[5] G Reddy Babu., (2013). "Effect of Nano-Silica on properties of Blended Cement" Vol 03 Issue, 5 pp. $50-55$.

[6] R. Roselin and Dr. M.S. Ravikumar (2018), Experimental Investigation on Concrete Using Nanosilica as Mineral Admixture, International Journal of Civil Engineering and Technology, 9(6), 2018, pp. 1464-1469.

[7] Rushabh A. Shah and Jayeshkumar R. Pitroda, "Assessment of Sorptivity and Water Absorption of Mortar with Partial Replacement of Cement by Fly Ash (CLASSF)", International Journal of Civil Engineering \& Technology (IJCIET), Volume 4, Issue 5, 2013, pp. 15 - 21, ISSN Print: 0976 - 6308, ISSN Online: 0976 - 6316.

[8] Alireza Naji Givi, Surya Abdul Rashid, Influence of 15 and 80 nano-SiO2 particles addition on mechanical and physical properties of ternary blended concrete incorporating rice husk ash. Composites (part B) Vol-42-s (2011) 562-569

[9] Rathi V. R, C.D. Modhera, Experimental study on effect of Colloidal Nano SiO2 and Fly Ash addition on properties of cement mortar, International Journal of Advanced Structures and Geotechnical Engineering ISSN 2319-5347, Vol. 03, No. 03

[10] Min-Hong Zhang and Jahidul Islam (2011) Use of Nano-silica to reduce Setting Time and Increase Early Strength of Concretes with High Volumes of Flyash or Slag, Construction and Building materials, 29, 573- 580

[11] Nura Bala, Madzlan Napiah and Ibrahim Kamaruddin (2017), Performance Evaluation of Composite Asphalt Mixture Modified with Polyethylene and Nanosilica, International Journal of Civil Engineering and Technology, 8(9), 2017, pp. 616-628.

[12] Kavitha S, Sandhiyadevi A (2015), "Experimental evaluation of the influence of Nanosilica on properties of concrete" Internation Journal of Innovative Science, Engineering \& Technology, Vol 3, Issue 6, ISSN (Online) 2348-7968, pp 644 - 648

[13] Sivakumar K, Jose Ravindra Raj B (2016), "Durability investigation on Nanosilica and Nano cement-based concrete" International Journal of Engineering and Management Research (IJEMR) Volume 6 Issue 2, ISSN (Online) 2250-0758, pp 314 - 315

[14] OSENI O. W. and AUDU T.M. (2016), The Effects of Percentage Compositon of Millet Stem Ash (MSA) and Water Cement Ratio on The Properties Composite Concrete, International Journal of Civil Engineering and Technology, 7(1), 2016, pp. 427-440.

[15] S.Gopinath, P.C.H. Mouli, A.R.Murthy, N.R.Iyer, S.Maheswaran, Effect of Nano silica on mechanical properties and durability of normal strength of concrete, Archives of Civil Engineering, LVIII,4, 2012. 